\title{
VIEIRA, Padre António. Sermóes I: Edição crítica. Lisboa: Imprensa Nacional-Casa da Moeda, 2008. 574p.
}

Gilson José dos Santos Universidade Federal de Minas Gerais

\begin{abstract}
P
ara celebrar os 400 anos de nascimento do Padre Antônio Vieira (1608-1697), foi lançado, em Portugal, em 2008, pela Imprensa Nacional-Casa da Moeda, a edição crítica do Tomo I dos Sermões desse proeminente pregador. A direção científica dessa edição é de Arnaldo do Espírito Santo e o consultor científico é Aníbal Pinto de Castro.

O volume é resultado do esforço coletivo de renomados pesquisadores portugueses e inicia o processo de divulgação de textos críticos do jesuíta. A iniciativa é louvável, sobretudo se se considerar o caráter pioneiro do trabalho. A edição, segundo a nota introdutória, é "a primeira que merece a designação de crítica, que será, a partir de agora, a obra de referência no quadro dos estudos vieirinos". Essa passagem audaciosa desperta no leitor, inevitavelmente, alguns questionamentos e reflexões. Por que tal empresa não foi realizada anteriormente? A nota não oferece resposta, mas o exemplo de Vieira ilustra o descaso de filólogos e linguistas brasileiros que têm condenado ao anonimato escritores ilustres da América Portuguesa. Se Vieira, o imperador da Língua Portuguesa, como bem o definiu o poeta Fernando Pessoa, não mereceu, até hoje, edição crítica, que
\end{abstract}


fim terá a obra de autores menos dotados de engenho e arte? O futuro não lhes parece promissor.

Outro aspecto relacionado a essa passagem da nota introdutória deve ser destacado: a autoridade atribuída a essa edição contrasta com sua pequena tiragem - de apenas 1.000 (mil) exemplares. Será que o famoso orador não teria mais de mil leitores, em Língua Portuguesa? Edições críticas deveriam ser universalizadas, para que os leitores formassem espírito crítico e os métodos de edição fossem aperfeiçoados.

A apresentação dos critérios da edição crítica inicia-se da seguinte forma: “Com este volume, dá-se finalmente a público uma edição segura, ao mesmo tempo fiel ao texto princeps e apresentada numa lição moderna [...]". Esse trecho sugere que, até então, não havia edição segura e fiel do texto da edição príncipe, o que põe em dúvida inúmeros estudos literários e linguísticos que se apoiaram em edições não-seguras. Essa questão lembra aos pesquisadores a urgência de edições críticas de obras literárias do nosso período colonial, capazes de fornecer textos bons para se ler e se trabalhar. Segue-se a eleição do texto-base, precedida de comentários referentes aos estados da edição príncipe, que, aqui, apresentaremos resumidamente.

O tomo I, dos Sermões, foi editado, primeiramente, em Lisboa, em 1679, pelo impressor régio João da Costa. Dessa edição, "restam três impressões [estados], iguais na empaginação e em parte dos elementos ornamentais, mas que apresentam variantes textuais e decorativas que as distinguem". Tais diferenças conduziram à classificação dos exemplares existentes em três grupos, a saber: $\boldsymbol{A}, \boldsymbol{B}$ e $\boldsymbol{C}$. Os exemplares de cada um desses estados apresentam uma errata, anteposta aos sermões, elaborada pelo próprio Vieira, por ocasião da revisão que fizera do texto impresso. Seria natural, então, que o texto $\boldsymbol{B}$ tivesse incorporado as correções feitas ao texto de $A$ e eliminado tal errata. Isso não sucedeu. O estado $C$, 
por outro lado, adotou as correções de $\boldsymbol{B}$, assinaladas na errata, mas preservou-a (a errata) como uma espécie de registro de que as alterações introduzidas no texto eram autorais.

Dessas informações, poder-se-ia inferir que os textos de $A$ e $\boldsymbol{B}$ são iguais entre si e que o de $\boldsymbol{C}$ traz, como variantes, apenas as correções contidas na errata e inseridas no corpo do texto. Curiosamente, porém, isso não se verifica: $\boldsymbol{B}$ e $\boldsymbol{C}$ alteraram, pontualmente, o texto de $A$, ora modificando grafias, ora substituindo por outra uma palavra ou expressão, ora introduzindo erros de leitura por inadvertência. $O$ confronto dos estados indica que $A$ é o mais arcaico, em termos ortográficos; $\boldsymbol{B}$ e $\boldsymbol{C}$, por outro lado, os mais modernizantes e com variantes que banalizam, por vezes, o sentido do texto.

A edição crítica do tomo I dos Sermões baseia-se na colação de exemplares de $\boldsymbol{A}, \boldsymbol{B}$ e $\boldsymbol{C}$. Dessa colação resulta a convicção fundamentada de que o exemplar $A$ transmite o melhor texto; ou seja, aquele que mais se aproxima da redação que lhe deu Vieira. Naturalmente, $\boldsymbol{A}$ foi eleito texto-base da edição crítica. Em seguida, apresentam-se os critérios propriamente ditos: "Como norma fundamental, optou-se por nunca ceder à actualização de grafias, quando estas implicassem uma realização fonética diferente daquela com que Vieira pronunciava as palavras".

Assim, formas como, por exemplo, reposta (= resposta) e resplandor (= resplendor) foram mantidas; e as formas equivalentes, no português atual, a esses vocábulos foram indicadas em notas, nas primeiras ocorrências delas, em cada sermão.

As formas ua, algua e nenhua são constantes em $A$, mas, em $B$ e $\boldsymbol{C}$, oscilam entre essas formas e uma, alguma e nenhuma. A observação da eufonia de construções, como, por exemplo, ocorrências de ua mão (em $A$ ), contraposta à cacofonia de uma $m \tilde{a} o$ (em $\boldsymbol{B}$ e $C$ ), indica que a forma empregada por Vieira é mais 
expressiva e traduz melhor o sentimento da língua. Acresce que, por se considerar tal variação significativa de um estado da evolução da língua portuguesa, mantiveram-se as formas empregadas por Vieira e assinalaram-se, no aparato, as variantes.

A distinção entre pôde e pode não é uniforme nos três estados, nem segura em todas as ocorrências. Anotam-se todos os casos em que se optou pela forma pôde.

Há inúmeras palavras cujas formas ou significados evoluíram e apresentam grande desvio relativamente ao Português atual. Citam-se alguns casos: padar (= paladar), correrse de (= envergonhar-se), encontrado (= contrário) e muitos outros casos. Essas formas vêm em negrito, no corpo do texto, indicando-se, dessa forma, que estão incluídas no vocabulário, no final do volume.

A pontuação original foi preservada, a fim de se manter o ritmo oratório do texto de Vieira, exceto nos casos em que da pontuação original pudessem advir dificuldades de leitura ou obscurecimento de sentido. Em certas ocorrências, como de uma pausa assinalada por vírgula entre o sujeito e o predicado, ou entre verbo e complemento direto, ou, ainda, entre verbo regente e oração completiva, foi eliminada. As intervenções na pontuação atualizam-na, conformando-a com as regras sintáticas atuais, mas apagam alguns aspectos prosódicos da pontuação de Vieira.

O editor observara que o emprego de maiúscula, em determinado contexto, reforça o significado de uma palavra. Assim, manteve, "escrupulosamente, o emprego de maiúsculas tal como surge no exemplar de $A^{\prime \prime}$. Além disso, grafou, com iniciais maiúsculas, pronomes pessoais e possessivos, nos casos em que têm por referente o nome de Deus ou de Maria (Mãe de Jesus). Assim justifica tal decisão: "Fizemo-lo por convenção, pois Vieira, em tais casos, serve-se das minúsculas". Esse critério é polêmico. Manter as iniciais maiúsculas presentes em 
$A$, respeitando a vontade do autor, por entender que tal recurso é estilístico - "reforça o significado de uma palavra" -, é legítimo; contudo, introduzir letra inicial maiúscula onde o autor emprega minúscula é desrespeitar sua vontade manifesta, uma vez que se destaca um termo que o autor não marcou formalmente, atribuindo-lhe certo significado ausente no contexto original.

As notas procuram esclarecer aspectos variados do texto, com anotações relacionadas às particularidades da língua praticada por Vieira e apontamentos de caráter histórico, literário, teológico, filosófico e cultural. De fato, essas notas iluminam a leitura e auxiliam o leitor a formular uma imagem melhor do tempo e do contexto em que os sermões foram pregados.

No final do volume, há um pequeno vocabulário, indicando a leitores menos familiarizados com a língua do século XVII as acepções pertinentes de formas raras ou que tiveram seus significados muito alterados com o passar do tempo.

O texto, editado sob essas normas gerais, pretende ser fiel à linguagem de Vieira, à sua vibração oratória e, ainda, acessível à leitura de estudantes e do público culto em geral. Apesar dos poucos senões apontados, a edição é meritória e representa enorme contribuição aos estudos no campo da Crítica Textual, da Língua Portuguesa e da Literatura lusobrasileira. Oxalá essa edição desperte em estudiosos brasileiros o interesse pela edição das obras de outros autores da América Portuguesa, esquecidas em arquivos e bibliotecas, como, por exemplo: Antônio de Sá, Eusébio de Matos, Anastácio Aires de Penhafiel, Rocha Pita e tantos outros. 